\title{
Interactive comment on "Rain-fed streams dilute inorganic nutrients but subsidise organic matter-associated nutrients in coastal waters of the northeast Pacific Ocean” by Kyra A. St. Pierre
} et al.

Kyra A. St. Pierre et al.

k.stpierre@oceans.ubc.ca

Received and published: 28 January 2021

The comment was uploaded in the form of a supplement:

https://bg.copernicus.org/preprints/bg-2020-350/bg-2020-350-AC1-supplement.pdf

Interactive comment on Biogeosciences Discuss., https://doi.org/10.5194/bg-2020-350, 2020. 